\title{
Effect of Different Pre-Sowing Treatments on Seed Germination of Spruce (Picea smithiana Wall. Boiss) Seeds under Temperate Conditions of Kashmir Himalayas, India
}

\author{
Javeed Ahmad Mugloo, Naseer A. Mir ${ }^{*}$, P.A. Khan, Gowher Nabi Perray and K.N. Kaisar \\ Faculty of Forestry, Sher-e-Kashmir University of Agriculture Science and Technology of \\ Kashmir, Benhama, Ganderbal, Jammu and Kashmir-191121, India \\ *Corresponding author
}

\begin{tabular}{|c|c|}
\hline & A B S T R A C T \\
\hline & \multirow{6}{*}{$\begin{array}{l}\text { The present study was carried out in laboratory at Faculty of Forestry Sher e-Kashmir } \\
\text { University of Agriculture Science and Technology of Kashmir, Benhama, Ganderbal, } \\
\text { Jammu and Kashmir during } 2011-2012 \text { to investigate the effect of different } \mathrm{GA}_{3} \\
\text { concentrations viz. 50, 100,150,200 and } 250 \mathrm{ppm} \text { on germinabiliy and growth of seeds } \\
\text { Picea smithiana under laboratory and nursery conditions imbibed for } 0,24 \text { and } 48 \text { hours } \\
\text { durations. From this study it was found that the seeds treated with } 200 \mathrm{ppm} \mathrm{GA}_{3} \text { for } 48 \\
\text { hours produced better germinability and growth both under laboratory and nursery } \\
\text { conditions. The maximum germination percentage under laboratory recorded was } 70.62 \% \\
\text { with the germination capacity of } 80.75 \% \text {, germination energy of } 48.99 \text {, germination speed } \\
\text { of } 28.52 \text { and germination value of } 5.90 \text {. Whereas the maximum germinability viz., } \\
\text { germination percentage, germination, germination value and plant percent of } 64.00,34.21 \text {, } \\
2.82 \text { and } 54.50 \text { respectively. The germination results indicated that Picea smithiana seeds } \\
\text { do possess inherent dormancy which increases with storage. Therefore it is advised that } \\
\text { spruce seeds should be imbibed in } 200 \text { ppm GA for } 48 \text { hours for better germination and } \\
\text { growth. }\end{array}$} \\
\hline Keywords & \\
\hline $\begin{array}{l}\mathrm{G} \\
\mathrm{K} \\
P i\end{array}$ & \\
\hline Article Info & \\
\hline $\begin{array}{l}\text { Accepted: } \\
\text { 26 September } 2017 \\
\text { Available Online: } \\
10 \text { November } 2017\end{array}$ & \\
\hline & \\
\hline
\end{tabular}

\section{Introduction}

Conifer seeds in general have a high degree of dormancy even if subjected to environmental conditions favourable for germination (Jull and Blazich, 2000). This dormancy is caused by a combination of internal (physiological) and external (physical) factors (Basu, 1994). Hard seed coat acts as a barrier for the imbibition of water and exchange of gases, essential for initiation of the germination process. Hard seed coats together with pericarps and other structural barriers impose a high mechanical resistance and block water uptake and/or oxygen diffusion (Kelly, 1992). Cold stratification has been widely used as a pre-sowing treatment for breaking dormancy to enhancing the seed germination rate (ISTA, 1976; Baskin and Baskin, 2004). This is an effortless, cheap and successful method for overcoming seed dormancy. The effects of moist chilling in establishing hormonal levels have been proved due to initiation of appropriate enzyme activity (Nikolaeva, 1969). Moreover, the phenomenon of cold stratification has long been recognized in 
overcoming physiological dormancy of seeds of many species (Baskin, and Baskin, 1987). Moist chilling breaks the dormancy and accelerates the rate of germination in physiologically dormant Picea glauca seeds (Wang, 1987). Moist chilling of dormant seeds may generally be efficacious, particularly if damage has accumulated due to natural deterioration or as a result of an imposed accelerated ageing regime (Mittal, 1987).

\section{Materials and Methods}

The present study "Effect of different presowing treatments on seed germination of spruce (Picea smithiana Wall. Boiss) seeds under temperate conditions of Kashmir Himalayas" was carried out in laboratory at Faculty of Forestry Sher e-Kashmir University of Agriculture Science and Technology of Kashmir, Benhama, Ganderbal, Jammu and Kashmir during 20112012 to investigate the effect of different $\mathrm{GA}_{3}$ concentrations on germinabiliy and growth of seeds Picea smithiana under laboratory and nursery conditions which were imbibed for three different durations. The treatment details are given in table below:

The experiment comprised of 13 treatments combinations (100 seeds/replication) in completely randomized design under laboratory conditions. After counting, seeds were placed in a petri dish with two fold germination paper and placed in a germinator with a calibrated temperature of $25 \pm 1^{\circ} \mathrm{C}$. All treatments were examined daily, seeds were considered germinated when the radicle was 5 $\mathrm{mm}$ long. Germination percentage and germination capacity, germination energy, germination speed and germination value was recorded daily following formulas given by (Sosa, 2005) as bellow:

Germination percentage $(\mathrm{GP})=\left(\frac{\mathrm{n}}{\mathrm{N}}\right) \times 100$
Germination capacity $(\mathrm{GC})=\left[\frac{(\mathrm{v}+\mathrm{n})}{\mathrm{N}}\right] \times 100$

where, $\mathrm{n}$ is the number of germinated seeds, $\mathrm{N}$ is the total number of seeds, $\mathrm{V}$ is the number of viable seeds recorded after conducting viability test using tetrazolium chloride (Peters, 2000) and D is the number of days to final germination.

Germination energy, germination speed and germination value was determined using the following formula given by Czabator (Czabator, 1962):

Germination energy $(\mathrm{GE})=\left(\frac{\mathrm{M}}{\mathrm{N}}\right) \times 100$

Where, $\mathrm{M}$ is cumulative germination up to time of maximum MDG reached at any time during the period of the test, $\mathrm{N}$ is the total number of seeds, $\mathrm{N}$ is the total number of seeds,

Germination speed $(\mathrm{GS})={ }^{\sum\left(\frac{\mathrm{n}}{\mathrm{d}}\right)}$

Where, $\mathrm{n}=$ number of germinated seeds, $\mathrm{d}=$ number of days

Germination value $(\mathrm{GV})=\mathrm{PV} \times \mathrm{MDG}$

Where, PV is the peak value of maximum means daily germination reached at any time during the period of the test.

The treated seeds were simultaneously sown in poly-bag (4"x7") also during the first week of the February, 2011 and 2012 in nursery. For the following paramaters: Germination $(\%)$, Germination energy (\%), Germination value, Seedling height $(\mathrm{cm})$, Collar diameter (mm), Root/shoot weight (g), Root:shoot ratio, Total biomass (g), Plant per cent.

The statistical analysis of each parameter was carried out on mean values and the analysis of 
variance (ANOVA) was performed using SPSS package (version 12.0). The critical difference (CD) $(5 \%)$ was calculated as: $\mathrm{CD}$ $=\mathrm{SEd} \mathrm{X} \mathrm{t}_{0.01}$, Where, SEd is the standard error of difference calculated as SEd = $\sqrt{ } 2 \mathrm{Me} / \mathrm{r}$, where $\mathrm{Me}=$ mean sum of square and $\mathrm{r}=$ number of replicates.

\section{Results and Discussion}

Enhancement of seed germination and improvement in seedling growth is controlled by plant hormones under favourable growth conditions. Several growth hormones are associated with seed germination and seedling physiology, but the most important being gibberellins, IAA and Kinetin (Faridi et al., 2000). These growth hormones function via activation of enzymes, mobilization of food materials leading to cell division, cell elongation and embryo growth that promotes germination in viable seeds (Khan, 1980). During germination and growth of embryonic axis, the carbohydrates and sugars are utilized to meet the requirement of active respiration and synthesis of cell wall and protoplasm materials for dividing and growing cells. The end products are transported to the growing axis to again provide raw materials for early growth of very young seedlings (Black, 1992). In the present investigation good quality spruce seeds were soaked in water for 24 or $48 \mathrm{~h}$ and also given $\mathrm{GA}_{3}$ treatment at $50,100,150,200$ or $250 \mathrm{ppm}$. Control seeds were not soaked or applied $\mathrm{GA}_{3}$. A total of 13 treatment combinations were evaluated for their impact on seed germinability parameters under laboratory and field conditions and seedling growth parameters under field conditions.

\section{Seed germination parameters}

\section{Laboratory conditions}

Gibberellins are the naturally occurring plant growth hormones. $\mathrm{GA}_{3}$ treatment can overcome dormancy in different seeds that have hard seed coat or dormant embryo. In most of the species survival percentage, growth and total biomass increased when seeds are pretreated with $\mathrm{GA}_{3}$. The result of the influence of gibberellic acid on seed germinability is presented in figure 1 . Germination percentages of Picea smithiana seeds with or without soaking by in $\mathrm{GA}_{3}$ over varied periods differed significantly $(\mathrm{p} \geq$ 0.05 ). Without $\mathrm{GA}_{3}$ seeds germinated low and started late. In contrast, when seeds were imbibed in different concentrations of $\mathrm{GA}_{3}$ for varying durations, the germination percentage rose to $39.50 \%$ without soaking (Control) to $75.50 \%$ when seeds were soaked in $200 \mathrm{ppm} \mathrm{GA}$ for $48 \mathrm{hrs}$, soaking alone in distilled water and lower concentrations of $\mathrm{GA}_{3}$ was ineffective in breaking dormancy of the seeds fully to produce the maximum germinability of the viable seeds, indicating that Picea smithiana seeds have physiological dormancy. Similar trend was observed for the other germination parameters viz. germination capacity $(85.50 \%)$, germination energy (55.46), germination speed (32.89) and germination value (10.58) when the seeds were imbibed in $200 \mathrm{ppm} \mathrm{GA}_{3}$ for $48 \mathrm{hrs}$ and differed significantly from the seeds which were socked 24 hour in 200 ppm GA 3 with germination percentage of $70.62 \%$, germination capacity of $80.75 \%$, germination energy of 48.99, germination speed of 28.52 and germination value of 5.90. The minimum germination parameters were recorded in the seeds which were sown without any treatment (control). The germination parameters increased with the increase in the $\mathrm{GA}_{3}$ concentration and socking duration up to 200 ppm and socked for 48 hours and decreased with the further increase in the $\mathrm{GA}_{3}$ concentration and socking duration.

\section{Nursery conditions}

Germination of the seeds treated with different $\mathrm{GA}_{3}$ concentrations (Fig. 2) revealed 
that germination parameters viz. germination percentage and germination energy increased and varied significantly at from $p \leq 0.05$ from $30.11 \%$ and $10.58 \%$ (control) to 64.00 to $34.21 \%$ (200 ppm $\mathrm{GA}_{3}$ for 24 hours) respectively. Similarly germination value and plant percent increased linearly and significantly at $\mathrm{p} \leq 0.05$ from 0.75 , and 19.90 $\%$ under control and reached maximum with 2.82 and 54.50 respectively when the seeds were treated with 200 ppm $\mathrm{GA}_{3}$ for 24 hours (Table 1) and decreased gradually after the further increased in the $\mathrm{GA}_{3}$ concentration and duration of imbibition under field conditions.

Application of $\mathrm{GA}_{3}$ exogenously has been reported to confer many beneficial effects. Omran et al., (1980) reported that $25 \mathrm{ppm}$ $\mathrm{GA}_{3}$ increased germination by about 40 per cent in zeera seeds. Also found an increase by 39.0 per cent in the seeds of Hibiscus esculenta at $400 \mathrm{ppm} \mathrm{GA}_{3}$ application. Increase in spruce of seed germination by optimum concentration of $\mathrm{GA}_{3}$ might probably have been due to enhancement of hydrolase (especially $\delta$-amlyse) synthesis as reported by Paleg (1960a and b; Amen 1968 or probably due to first initiation of embryo growth and subsequent synthesis of more $\mathrm{GA}_{3}$ that might have induced hydrolase synthesis (Chen and Varnes, 1973). Several studies have shown gibberellins to be an effective germination stimulator (Sofi, 2005; Lavania et al., 2006). An increase in germination of chilgoza pine seeds by increasing soaking periods was probably attributed to enhancement of hydrolase (especially amylase) synthesis, as reported by Bewley and Black (1994) and Chen et al., (2008)

ABA is reported to be present in the pericarp and seed coat of some plant species that inhibits germination (Leadem, 1987). Cold stratification followed by $\mathrm{GA}_{3}$ application has been found to suppress this inhibition and enhance germination (Mcbridge and Dickson, 1972) spruce seeds. Shivani (2003) observed increase in the germinability of Abies pindrow seeds after $24 \mathrm{~h}$ soaking in water at $2-3^{\circ} \mathrm{C}$ under laboratory conditions and $48 \mathrm{~h}$ water soaking at $2-3^{\mathrm{O}} \mathrm{C}$ under field conditions, followed by $200 \mathrm{ppm} \mathrm{GA}_{3}$, soaking for $24 \mathrm{~h}$.

In Picea smithiana soaking of seeds for $24 \mathrm{~h}$ at $2-3^{\mathrm{O}} \mathrm{C}+100 \mathrm{ppm} \mathrm{GA}_{3}$ application increased germination under laboratory conditions but under field conditions $48 \mathrm{~h}$ soaking in water was good. Lavania et al., (2006) observed that for higher germination Pinus wallichiana seeds required more soaking period for lower $\mathrm{GA}_{3}$ concentration $(100 \mathrm{ppm}$ for $36 \mathrm{~h})$ than for higher concentration (200 ppm $\mathrm{GA}_{3}$ for $24 \mathrm{~h}$ ) to get the comparable germination.

Exogenous application of GA3 has been reported to be effective in breaking dormancy and substituting for the chilling requirement in seeds of many species (Smiris et al., 2006; Pipinis et al., 2012).

The treatment details are given in table below

\begin{tabular}{|l|l|l|l|}
\hline S. no & \multicolumn{1}{|c|}{ Treatment details } & S. no & \multicolumn{1}{c|}{ Treatment details } \\
\hline $\mathrm{T}_{1}$ & Control & $\mathrm{T}_{8}$ & Soaking in $\mathrm{GA}_{3}(150 \mathrm{ppm})$ for 24 hours \\
\hline $\mathrm{T}_{2}$ & Soaking in cold water for 24 hours & $\mathrm{T}_{9}$ & Soaking in $\mathrm{GA}_{3}(150 \mathrm{ppm})$ for 48 hours \\
\hline $\mathrm{T}_{3}$ & Soaking in cold water for 48 hours & $\mathrm{T}_{10}$ & Soaking in $\mathrm{GA}_{3}(200 \mathrm{ppm})$ for 24 hours \\
\hline $\mathrm{T}_{4}$ & Soaking in $\mathrm{GA}_{3}(50 \mathrm{ppm})$ for 24 hours & $\mathrm{T}_{11}$ & Soaking in $\mathrm{GA}_{3}(200 \mathrm{ppm})$ for 48 hours \\
\hline $\mathrm{T}_{5}$ & Soaking in $\mathrm{GA}_{3}(50 \mathrm{ppm})$ for 48 hours & $\mathrm{T}_{12}$ & Soaking in $\mathrm{GA}_{3}(250 \mathrm{ppm})$ for 24 hours \\
\hline $\mathrm{T}_{6}$ & Soaking in $\mathrm{GA}_{3}(100 \mathrm{ppm})$ for 24 hours & $\mathrm{T}_{13}$ & Soaking in $\mathrm{GA}_{3}(250 \mathrm{ppm})$ for 48 hours \\
\hline $\mathrm{T}_{7}$ & Soaking in $\mathrm{GA}_{3}(100 \mathrm{ppm})$ for 48 hours & & \\
\hline
\end{tabular}


Fig.1 Effect of pre-sowing treatments on seed germinability of Spruce (Picea smithiana, Wall. Boiss) seed under labortary conditions pooled over the year 2011 and 2012

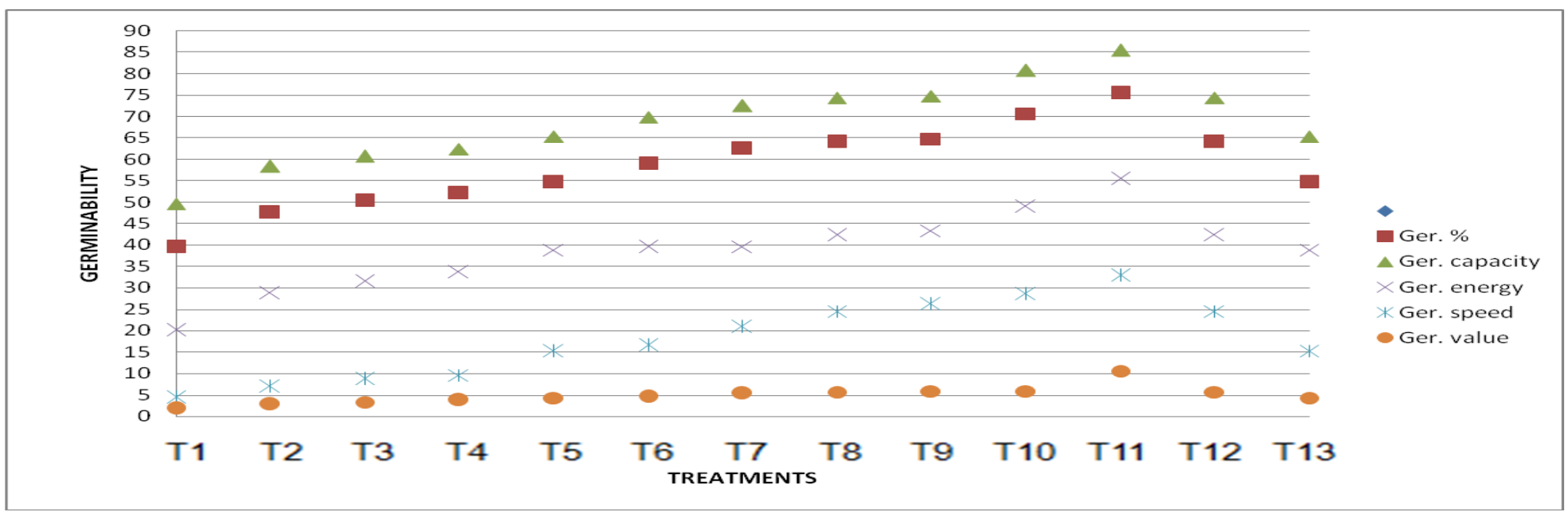

Fig.2 Effect of pre-sowing treatments on seed germination (\%)and germination energy of Spruce (Picea smithiana, Wall. Boiss) seed under field conditions pooled over the year 2011 and 2012

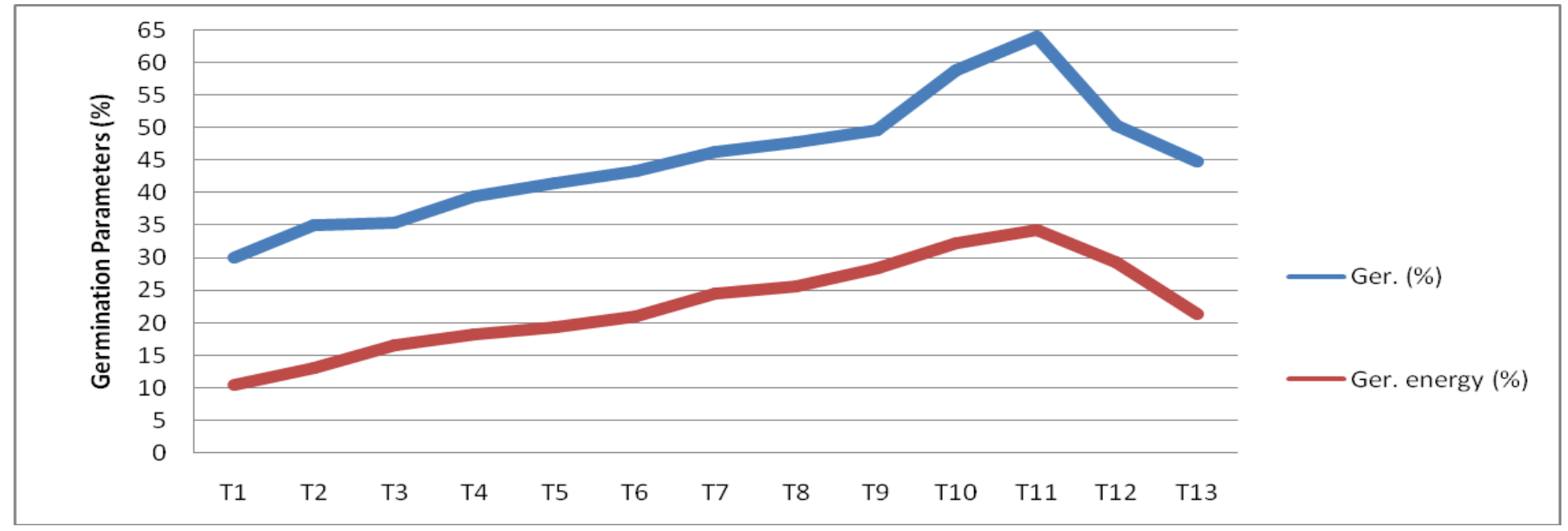


Table.1 Effect of pre-sowing treatments on seed germination value and plant per cent of Spruce (Picea smithiana, Wall. Boiss) seed under field conditions pooled over the year 2011 and 2012

\begin{tabular}{|c|c|c|}
\hline Treatments & Germination value & Plant per cent \\
\hline $\mathrm{T}_{1}$ : Control & 0.75 & $19.90(4.40)$ \\
\hline $\mathrm{T}_{2}:$ Soaking in cold water for $24 \mathrm{hrs}$ & 0.88 & $23.33(4.90)$ \\
\hline $\mathrm{T}_{3}$ : Soaking in cold water for $48 \mathrm{hrs}$ & 1.00 & $25.00(5.00)$ \\
\hline $\mathrm{T}_{4}$ : Soaking in $\mathrm{GA}_{3} 50 \mathrm{ppm}$ for $24 \mathrm{hrs}$ & 1.05 & $29.83(5.54)$ \\
\hline $\mathrm{T}_{5}$ : Soaking in $\mathrm{GA}_{3} 50 \mathrm{ppm}$ for $48 \mathrm{hrs}$ & 1.08 & $31.50(5.61)$ \\
\hline $\mathrm{T}_{6}:$ Soaking in $\mathrm{GA}_{3} 100 \mathrm{ppm}$ for $24 \mathrm{hrs}$ & 1.21 & $35.66(5.97)$ \\
\hline $\mathrm{T}_{7}$ : Soaking in $\mathrm{GA}_{3} 100 \mathrm{ppm}$ for $48 \mathrm{hrs}$ & 1.44 & $36.83(6.15)$ \\
\hline $\mathrm{T}_{8}$ : Soaking in $\mathrm{GA}_{3} 150 \mathrm{ppm}$ for $24 \mathrm{hrs}$ & 1.52 & $38.16(6.17)$ \\
\hline $\mathrm{T}_{9}$ : Soaking in $\mathrm{GA}_{3} 150 \mathrm{ppm}$ for $48 \mathrm{hrs}$ & 1.74 & $40.16(6.33)$ \\
\hline $\mathrm{T}_{10}$ : Soaking in GA $200 \mathrm{ppm}$ for $24 \mathrm{hrs}$ & 1.86 & $49.33(7.02)$ \\
\hline $\mathrm{T}_{11}$ : Soaking in $\mathrm{GA}_{3} 200 \mathrm{ppm}$ for $48 \mathrm{hrs}$ & 2.82 & $\mathbf{5 4 . 5 0}(7.38)$ \\
\hline $\mathrm{T}_{12}$ : Soaking in $\mathrm{GA}_{3} 250 \mathrm{ppm}$ for $24 \mathrm{hrs}$ & 1.89 & $40.50(6.36)$ \\
\hline $\mathrm{T}_{13}$ : Soaking in $\mathrm{GA}_{3} 250 \mathrm{ppm}$ for $48 \mathrm{hrs}$ & 1.22 & $34.83(5.90)$ \\
\hline $\mathrm{CD}(\mathbf{p} \leq \mathbf{0 . 0 5})$ & 0.04 & 0.54 \\
\hline
\end{tabular}

Figures in parentheses are square root transformed values.

Table.2 Effect of pre-sowing treatments on growth and biomass of Spruce (Picea smithiana, Wall. Boiss) seedling under field conditions pooled over the year 2011 and 2012

\begin{tabular}{|c|c|c|c|c|c|c|c|c|}
\hline Treatments & $\begin{array}{c}\text { Plant } \\
\text { height }(\mathbf{c m})\end{array}$ & $\begin{array}{c}\text { Collar } \\
\text { diameter }(\mathrm{mm})\end{array}$ & $\begin{array}{c}\text { Fresh shoot } \\
\text { weight }(\mathrm{g})\end{array}$ & $\begin{array}{l}\text { Dry shoot } \\
\text { weight }(g)\end{array}$ & $\begin{array}{l}\text { Fresh root } \\
\text { weight (g) }\end{array}$ & $\begin{array}{c}\text { Dry root } \\
\text { weight }(g)\end{array}$ & $\begin{array}{c}\text { Shoot root } \\
\text { ratio }\end{array}$ & $\begin{array}{c}\text { Total } \\
\text { biomass }(\mathrm{g})\end{array}$ \\
\hline $\mathrm{T}_{1}:$ Control & 1.967 & 0.218 & 0.083 & 0.013 & 0.027 & 0.013 & 1.167 & 0.110 \\
\hline $\mathrm{T}_{2}$ : Soaking in cold water for $24 \mathrm{hrs}$ & 2.200 & 0.302 & 0.063 & 0.009 & 0.010 & 0.009 & 1.000 & 0.073 \\
\hline $\mathrm{T}_{3}$ : Soaking in cold water for $48 \mathrm{hrs}$ & 2.967 & 0.586 & 0.142 & 0.022 & 0.108 & 0.012 & 1.833 & 0.250 \\
\hline $\mathrm{T}_{4}$ : Soaking in $\mathrm{GA}_{3} 50 \mathrm{ppm}$ for $24 \mathrm{hrs}$ & 3.100 & 0.671 & 0.180 & 0.010 & 0.130 & 0.010 & 1.000 & 0.310 \\
\hline $\mathrm{T}_{5}$ : Soaking in $\mathrm{GA}_{3} 50 \mathrm{ppm}$ for $48 \mathrm{hrs}$ & 3.200 & 0.807 & 0.210 & 0.013 & 0.147 & 0.030 & 0.433 & 0.357 \\
\hline $\mathrm{T}_{6}$ : Soaking in $\mathrm{GA}_{3} 100 \mathrm{ppm}$ for $24 \mathrm{hrs}$ & 3.333 & 0.935 & 0.227 & 0.068 & 0.207 & 0.028 & 2.428 & 0.434 \\
\hline $\mathrm{T}_{7}$ : Soaking in $\mathrm{GA}_{3} 100 \mathrm{ppm}$ for $48 \mathrm{hrs}$ & 3.600 & 1.167 & 0.233 & 0.033 & 0.150 & 0.017 & 1.941 & 0.383 \\
\hline $\mathrm{T}_{8}$ Soaking in GA $150 \mathrm{ppm}$ for $24 \mathrm{hrs}$ & 3.633 & 1.185 & 0.260 & 0.063 & 0.230 & 0.033 & 1.909 & 0.490 \\
\hline T Soaking in $\mathrm{GA}$ 150ppm for $48 \mathrm{hrs}$ & 4.833 & 1.205 & 0.268 & 0.062 & 0.208 & 0.025 & 2.480 & 0.476 \\
\hline $\mathrm{T}_{10}$ : Soaking in $\mathrm{GA}_{3} 200 \mathrm{ppm}$ for $24 \mathrm{hrs}$ & 4.367 & 1.268 & 0.268 & 0.075 & 0.220 & 0.030 & 2.500 & 0.498 \\
\hline $\mathrm{T}_{11}$ : Soaking in GA $200 \mathrm{ppm}$ for $48 \mathrm{hrs}$ & 5.000 & 1.330 & 0.293 & 0.085 & 0.233 & 0.033 & 2.578 & 0.53 \\
\hline $\mathrm{T}_{12}$ : Soaking in GA $250 \mathrm{ppm}$ for $24 \mathrm{hrs}$ & $4.800^{-}$ & 1.322 & 0.290 & 0.083 & 0.222 & 0.029 & 2.568 & 0.512 \\
\hline $\mathrm{T}_{13}$ : Soaking in $\mathrm{GA}_{3} 250 \mathrm{ppm}$ for $48 \mathrm{hrs}$ & 2.950 & 0.666 & 0.162 & 0.028 & 0.123 & 0.020 & 1.400 & 0.285 \\
\hline $\mathrm{CD}(\mathbf{p} \leq \mathbf{0 . 0 5})$ & $\mathbf{0 . 2 3 3}$ & 0.089 & $\mathbf{0 . 0 2 0}$ & 0.013 & 0.011 & 0.013 & 1.025 & 0.026 \\
\hline
\end{tabular}


Ghayyad et al., (2010) reported that GA3 is effective in shortening the chilling requirement. However, in the present study, the application of GA3 treatments separately showed zero germination percentage.

\section{Seedling growth parameters}

The results (Table 2) revealed the seedling growth characteristics improved and varied significantly at $p \geq 0.05$ with the increase in $\mathrm{GA}_{3}$ and soaking duration maximum seedling growth parameters viz. plant height of 5.00 $\mathrm{cm}$, collar diameter with $1.33 \mathrm{~mm}$, fresh shoot weight with $0.29 \mathrm{~g}$, dry shoot weight with $0.08 \mathrm{~g}$, fresh root weight with $0.23 \mathrm{~g}$, dry root weight with $0.03 \mathrm{~g}$, shoot root ratio with 2.5 and total biomass with $0.53 \mathrm{~g}$ were recorded when the seeds were soaked in $200 \mathrm{ppm} \mathrm{GA} 3$ for 48 hours and decreased with the further increase $\mathrm{GA}_{3}$ concentration, which was at par with the seeds which were soaked in the 250 ppm for 24 hours with the plant height of $4.800 \mathrm{~cm}$, collar diameter $1.32 \mathrm{~mm}$, fresh shoot weight $0.29 \mathrm{~g}$, dry shoot weight 0.083 $\mathrm{g}$, fresh root weight $0.22 \mathrm{~g}$, dry root weight $0.029 \mathrm{~g}$, shoot root ratio 2.56 and total biomass $0.512 \mathrm{~g}$. Whereas the minimum seedling growth parameters were recorded in the seeds which were directly sown in the poly bags without any treatment (control).

The increase in growth of the three species studied under high $\mathrm{GA}_{3}$ level may be due to increased cell elongation, cell division and stem elongation, resulting in an increased plant growth. The findings with pretreatment of seeds are similar to observations of other investigations (Singh et al., 1984) who have reported that $\mathrm{GA}_{3}$ enhances the growth of seedlings of several forest tree species. Cytokinins does not appear essential for seed germination but during germination, cytokinins appear to offset the effect of inhibitors, notably ABA. It has been described, as playing a permissive role in germination in allowing gibberellins to function (Leubner-Metzger, 2005). Gibberellins prominently involved in seed germination and mobilization of endosperm reserves during early embryo growth as well as flower and fruit development Hopkins and Huner (2004). It was found that GA increases the growth potential of embryo and promotes germination and is necessary to overcome the mechanical restraint conferred by the seed covering layers by weakening of the tissues surrounding the radicle (Finch-Savage and Leubner-Metzger, 2006).

The preceding results suggest that $\mathrm{GA}_{3}$ exerted a significant influence on growth growth parameters. This influence on growth parameters might be explained through the role of $\mathrm{GA}_{3}$ in enhancing gibberellin synthesis, which in turn leads to increase in the branching and their overall growth (Penfield et al.,2005). The results of the present study are in agreement with Parvin et al., (2015) who reported root length of 24.58 $\mathrm{cm}$, root volume of $7.63 \mathrm{~cm}^{3}$ and root area of $18.64 \mathrm{~cm}^{2}$ for Juglans nigra subjected to 2 months of stratification and application of 400 ppm $\mathrm{GA}_{3}$.

$\mathrm{GA}_{3}$ has been found to stimulate the growth of stems particularly those of rosette plants (Jones, 1973). Soaking of seeds in different concentrations of $\mathrm{GA}_{3}$, IAA and IBA has been found to increase cell division, cell elongation and chlorophyll synthesis (Mukaila et al., 1997). Pandiya (1989) has reported that $\mathrm{GA}_{3}$ application hastens seed germination by inducing embryo development and/or neutralizing the growth inhibitors present in the seed coat.

Among the thirteen different pre-sowing treatments, under laboratory conditions, the maximum germination per cent (75.50), germination capacity $(85.50 \%)$, germination energy $(55.46 \%)$, germination speed (32.89) 
and germination value (10.58) were recorded in seeds treated with $\mathrm{GA}_{3} 200 \mathrm{ppm}$ for 48 hours. Under nursery conditions, the maximum germination $(64.00 \%)$, germination energy (34.21\%) and germination value (2.82), plant height $(5.00 \mathrm{~cm})$, collar diameter $(1.330 \mathrm{~mm})$, fresh shoot weight $(0.293 \mathrm{~g})$, dry shoot weight $(0.085 \mathrm{~g})$, fresh root weight $(0.233 \mathrm{~g})$, dry root weight $(0.033 \mathrm{~g})$, shoot root ratio (2.578), total biomass $(0.526 \mathrm{~g})$ and plant per cent $(54.50 \%)$ was recorded in $\mathrm{GA}_{3}$ 200 ppm seeds soaked for 48 hours $\left(T_{11}\right)$. Therefore it is recommended that spruce seeds should be imbibed in 200 ppm $\mathrm{GA}_{3}$ for 48 hours for better germination and growth.

\section{References}

Amen, R. D. 1968. A model of seed dormancy. Bot. Rev. 34: 1-31.

Baskin, C. C, Baskin, J. M. 1987, Seeds: Ecology, biogeography, and evolution of dormancy and germination. Academic Press, San Diego; 1998. Wang XH. Nursery trial with introduced Cedrus deodara seeds. Forest Science Tech. 2:1-2.

Baskin, J. M and Baskin, C. C. 2004. A classification system for seed dormancy. Seed Science Research 14:116.

Basu, R. N. 1994. An appraisal of research on wet and dry physiological seed treatment and their applicability with special reference to tropical and subtropical countries. Seed Science Technology 22:107-126.

Bewley, J. D and Black, M. 1994. Seeds. Physiology of Development and Germination. Second Edition. New York, Plenum Press P. 445.

Black, M. 1992. Control processes in germination and dormancy. Oxford Biology Readers Services No. 20 (Head. J. J. and O. F. Lowenstein, eds). Oxford University Press, London, pp. 1-
16.

Chen, S. S. C. and Varnes, V. F. 1973. Hormones and seed dormancy. Seed Science and Technology 1: 325-328.

Chen, S. Y., Kuo, S. R., \& Chien, C. T. 2008. Roles of gibberellins and abscisic acid in dormancy and germination of red bayberry (Myricarubra) seeds. Tree Physiology, 28(9):1431-1439.

Czabator, F. J. 1962. Germination value: An index of combining speed and completeness of pine seed germination. Forest Science 8:386-396.

Faridi, I. O., Samani, E. R. T., Kadiri M. and Agboola, D. A. 2000. Studies on growth inhibitors and promoters in dormant and germinability seeds of Parkia biglobosa. Nigerian Journal of Botany 13: 89-95.

Finch-Savage, W. E and Leubner-Metzger, G. 2006. Seed dormancy and the control of germination. New Phytologist. 171, 501-523.

Ghayyad, M., Kurbysa, M and Napolsy, G. 2010. Effect of endocarp removal, gibberelline, stratification and sulfuric acid on germination of Mahaleb (Prunus mahaleb L.) seeds. AmericanEurasian ournal of Agricultural and Environmental Science. 9:163-168.

ISTA. 1976. International rules for seed testing. Rules and annexes. Inter. Seed Testing Assoc. Seed Science Technology 4:3-117.

Jones, R. L. 1973. Gibberelline: their physiological role. Annual Rev. Plant Physiology 24: 571-598.

Jull, L. G and Blazich, F. A. 2000. Seed germination of selected provenances of Atlantic white cedar as influenced by stratification temperature and light. Horti Scientista 35:132-135.

Karam, N. S and Al-Salem, M. M. 2001. Breaking Dormancy in Arbutus and rachne L. by Stratification and Gibberellic acid. Seed Science and Technology. 29, 51-56. 
Kelly, K. M., Vanstanden, J., Bell, W. E. 1992. Seed coat structure and dormancy. Plant Growth Regulators 11:201-209.

Khan, A. A. 1980. The physiology and biochemistry of seed dormancy and germination. North Holland Co., New York, p. 312.

Lavania, S. K., Singh, R. P. and Singh, V. 2006. Effect of gibberellic acid and $\mathrm{pH}$ on seed germination in blue pine (Pinus wallichiana, A. B. Jacks). Indian Forester 132(7): 1024-1028.

Leadem, C. L. 1987. Role of plant growth regulators in the germination of forest tree seeds. In: Hormonal control of tree growth. Proceedings of the Physiology Working Group Technical Session (Ed. Korsuth and Ross). Society of American Foresters National Convention, Birmingham, Alabama, USA, Oct.6-9. Martinus Nijhoff Pub. Netherlands, pp. 61-93.

Mcbridge, J. R. and Dickson, R. 1972. Growth inhibitor reversed gibberellic citric acid and stratification enhance white ash germination. Tree Planters Note 23: 1-2.

Mittal, R. K and Wang, B. S. P. 1987. Fungi associated with seeds of eastern white pine and white spruce during cone processing and seed extraction. Canadian Journal of Forest Research 17: 1026-1034.

Mukaila, M., Muktar, K. and Agboola, D. A. 1997. Response of some Nigerian vegetables to plant growth regulator treatments. Revista Biologia Tropical 44(37/45(1): 23-28.

Nikolaeva, MG. 1969. Physiology of deep dormancy in seeds Izdatel'styo "Nauka;" leningrad Translated from Russian by Z. Shapiro, National Science Foundation, Washington, DC. 248.

Omran, A. F., EL-Bakry, A. M. and Gawish, R. A. 1980. Effect of soaking seeds in some growth regulator solutions on the growth. Chemical constituents and yield of okra. Seed Science and Technology 8: 161-168.

Paleg, L. G. 1960a. Physiological effect of gibberellic acid I. On carbohydrates metabolism and amalyse activity of barley endosperm. Plant Physiology 35: 293-299.

Paleg, L. G. 1960b. Physiological effects of gibberellic acid II. On starch hydrolyzing enzymes of barley endosperm. Plant Physiology 35: 902906.

Pandiya, S. 1989. Improving Forest production through quality seeds. $J$. Tropical Fort 5(11): 251-255.

Parvin, P., Khezri, M., Tavasolian, I., \& Hosseini, H. 2015. The effect of gibberellic acid and chilling stratification on seed germination of Eastern black walnut (Juglans nigra L.). Journal of Nut, 6, 67-76.

Penfield, S., Josse, E. M., Kannangara, R., Gilday, A. D., Halliday, K. J., \& Graham, I. A. 2005. Cold and light control seed germination through the bHLH transcription factor spatula. Current Biology, 15, 1998-2006.

Peters, P. 2000. Tetrazolium testing handbook. Contribution No. 29. The hand book on seed testing. Prepared by tetrazolium subcommittee of the association of official seed analysis. Part 2. Lincoln, Nebraska.

Pipinis, E., Milios, E., Mavrokordopoulou, O., Gkanatsiou, C. H., Aslanidou, M and Smiris, P. 2012. Effect of Pretreatments on Seed Germination of (Prunus mahaleb L.). Notulae Botanicae Horti Agrobotanic. 40:183189.

Shivani, D. 2003. Effect of stratification and plant bio-regulator on the germination of fir and spruce. M. Sc. Thesis, Dr. Y. S. Parmar University of Horticulture 
and Forestry, Nauni, Solan, India, pp. 102.

Singh, V. and Singh, R. V. 1984. Seed dispersal, seed germination and seedling establishment in natural forests of silver fir and spruce-II. Seed germination and seedling establishment. Indian Forester 110(7): 632-639.

Smiris, P., Pipinis, E., Aslanido, M., Mavrokordopoulou, O., Milios, E and Kouridakis, A. 2006. Germination study on Arbutus unedo L. (Ericaceae) and Podo cytisus caramanicus Boiss and Heldr (Fabaceae). Journal of Biological
Research. 5: 85-91.

Sofi, P. A. 2005. Standardization of nursery technology of Cedrus deodara. Ph. D. Thesis, Dr. Y. S. Parmar University of Horticulture and Forestry, Nauni, Solan, India, pp. 176.

Sosa, L., Lanes, A., Reinoso, H., Reginato, M and Luna, V. 2005. Osmotic and specific ion effects on the germination of Prosopis strombulifera. Annals of Botany 96:261-267.

Wang, X. H. 1987. Nursery trial with introduced Cedrus deodara seeds. For. Sci. Tech. 2:1-2.

\section{How to cite this article:}

Javeed Ahmad Mugloo, Naseer A. Mir, P.A. Khan, Gowher Nabi Perray and Kaisar, K.N. 2017. Effect of Different Pre-Sowing Treatments on Seed Germination of Spruce (Picea smithiana Wall. Boiss) Seeds under Temperate Conditions of Kashmir Himalayas, India. Int.J.Curr.Microbiol.App.Sci. 6(11): 3603-3612. doi: https://doi.org/10.20546/ijcmas.2017.611.422 